Original Article

\title{
Prevalence of low back pain and associated factors among farmers during the rice transplanting process
}

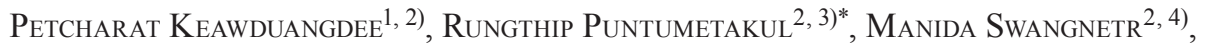
Wongsa Laohasiriwong ${ }^{5)}$, Dariwan Settheetham ${ }^{6}$, Junichiro Yamauchi $^{7}{ }^{7}$ ), Rose Boucaut $^{9}$

1) Faculty of Public Health, Khon Kaen University, Thailand

2) Research Center in Back, Neck, Other Joint Pain and Human Performance (BNOJPH), Khon Kaen University: 123 Moo 16 Mitraphab street, Muang District, Khon Kaen 40002, Thailand

3) School of Physical Therapy, Faculty of Associated Medical Sciences, Khon Kaen University, Thailand

4) Program of Production Technology, Faculty of Technology, Khon Kaen University, Thailand

5) Department of Public Health Administration, Faculty of Public Health, Board Committee of Research and Training Centre for Enhancing Quality of Life of Working Age People (REQW), Khon Kaen University, Thailand

6) Department of Environmental Health Science, Faculty of Public Health, Khon Kaen University, Thailand

7) Graduate School of Human Health Science, Tokyo Metropolitan University, Japan

8) Future Institute for Sport Science, Japan

9) School of Health Science (Physiotherapy), University of South Australia, Australia

\begin{abstract}
Purpose] The aim of this study was to investigate the prevalence of low back pain and associated factors in Thai rice farmers during the rice transplanting process. [Subjects and Methods] Three hundred and fortyfour farmers, aged 20-59 years old, were asked to answer a questionnaire modified from the Standard Nordic Questionnaire (Thai version). The questionnaire sought demographic, back-related, and psychosocial data. [Results] The results showed that the prevalence of low back pain was $83.1 \%$. Farmers younger than 45 years old who worked in the field fewer than six days were more likely to experience low back pain than those who worked for at least six days. Farmers with high stress levels were more likely to have low back pain. [Conclusion] In the rice transplanting process, the low back pain experienced by the farmers was associated with the weekly work duration and stress.

Key words: Low back pain, Rice farmers, Rice transplanting process
\end{abstract}

(This article was submitted Feb. 26, 2015, and was accepted Apr. 13, 2015)

\section{INTRODUCTION}

Farming, particularly rice farming, is an important occupation in Thailand. Rice is the most important product for consumption and export. Nowadays, agricultural production of rice is easier in developed countries than in the past due to technological progress. However, in developing countries, use of agricultural technology is limited. For this reason, farmers in developing countries, such as in some areas of India, Myanmar, Laos, and Thailand, use traditional methods involving manual work. Rice farming consists of many manually performed tasks including transplanting and sowing. Consequently, it is not surprising that there is a high prevalence of work-related musculoskeletal disease among

*Corresponding author. Rungthip Puntumetakul (E-mail: rungthiprt@gmail.com)

C2015 The Society of Physical Therapy Science. Published by IPEC Inc. This is an open-access article distributed under the terms of the Creative Commons Attribution Non-Commercial No Derivatives (by-ncnd) License $<$ http://creativecommons.org/licenses/by-nc-nd/3.0/> . rice farmers ${ }^{1,2)}$

Low back pain (LBP) is a common health problem arising from work with manual handling ${ }^{3,9}$, especially in farmers $\left.{ }^{4}, 5\right)$. The literature confirms that the prevalence of LBP among farmers is high, particularly in developing countries ${ }^{1,2)}$. A number of studies have reported LBP to be highly prevalent in rice farmers. For example, in Thailand, there are reports indicating that the prevalence of LBP in rice farmers is between $56 \%$ and $73.1 \%{ }^{1,2)}$. Furthermore, one of these studies indicated that the highest prevalence of LBP arises during the transplanting process ${ }^{1)}$, which is a most tedious job.

LBP can arise due to many factors, which can be divided into three main categories. The first category is personal factors including age, body mass index (BMI), exercise, alcohol consumption, and smoking ${ }^{6,7)}$. The second category is psychosocial factors including anxiety, depression, somatization of symptoms, stress, job dissatisfaction, negative body image, and poor self-esteem ${ }^{8,10)}$. The third category is physical occupational factors including repetitive motion, heavy lifting, non-neutral postures, and vibration ${ }^{11,12)}$. Contemporary literature has simply suggested that occupational 
factors, especially working postures, are the main causes of $\mathrm{LBP}^{12,13)}$. Consequently, LBP prevalence has been found highest in the transplanting process of rice farming because manual transplanting is a labor-consuming and tiresome job.

In Thailand, the transplanting process is a complex activity. Chronologically, it is closely associated with harrowing, plowing, and the gathering of saplings in the main field. In Thailand, the transplanting process involves standing in a waterlogged field and bending to put seedlings into the soil by hand, frequently and over a long time period. Therefore, the transplanting process involves harmful postures consisting of prolonged stooping and repetitive twisting. Accordingly, it typically impacts the low back region, resulting in pain. It is well known that working postures during transplanting are related to LBP; however, every farmer has their own individual demands, which can be defined as external load factors. These factors may include prior work experience, hours of work, work intensity, and stress, which are also related to $\mathrm{LBP}^{14,15)}$.

Episodes of LBP are typically brief, and so many farmers may not seek medical care. It has been noted that LBP is usually resolved within one month. Nevertheless, recent studies indicated that LBP can persist for 6 months and commonly recurs within one year. There are few studies about the external load factors associated with LBP. Therefore, the current study aimed to investigate the point prevalence of LBP and associated external load factors among Thai rice farmers during the transplanting process.

\section{SUBJECTS AND METHODS}

A cross-sectional study was conducted during the rice transplanting process in the period from July to August 2013. The farmers, aged between 20 and 59 years, were randomly invited to participate in the study by face-to-face communication. Subjects with underlying diseases such as systematic inflammation, a severe nerve injury, a past history of back pain caused by accidents, and uncontrolled psychological problems were excluded ${ }^{12}$. Based on the proportion of farmers experiencing $\mathrm{LBP}^{1)}$, a logistic regression formula was used to calculate the sample size ${ }^{16)}$. The proportion of farmers experiencing LBP and an odds ratio for the relationship between LBP and gender, which were 0.76 and 2.8 , respectively ${ }^{1}$, were applied to calculate the sample size of the study based on a significance level of 0.05 and $80 \%$ power. The approximate sample size was $n=344$.

Subjects meeting the inclusion criteria, that is, those who were aged between 20-59 years old and performed the manual transplanting process, were sent a letter inviting them to participate in the study and an information sheet about it. They were asked to answer the questionnaire with the assistance of interviewers. The Human Ethics committee of Khon Kaen University (KKU) approved the study protocol.

The questionnaire, including short-answer questions, was divided into 3 parts: i) personal characteristics and farming characteristics, ii) LBP problems, and iii) psychosocial issues. The first part of the questionnaire sought personal information based on a literature review about factors associated with LBP. These variables included gender, age, body weight and body stature, level of exercise, smoking, and ad- ditional income ${ }^{12)}$. Questions about farming characteristics were also added to this part. These included questions about farming experience, number of days in the field, number of bundles of seedlings planted each day, weight of a bundle, and duration of transplanting (in days), as some previous studies demonstrated that these variables may influence $\mathrm{LBP}^{14,15)}$.

The second part of questionnaire aimed to establish the prevalence of LBP during the rice transplanting process and to determine the prevalence of disorders of musculoskeletal structures. This part used a Standard Nordic Questionnaire (Thai version) $)^{12,17)}$. The first question was phrased as "have you had trouble or LBP in the area shown that lasted for a day?" to which participants provided a "yes" or "no" response. Respondents were defined as cases in this study if they reported that they had experienced LBP that lasted for at least 24 hours between the 12th thoracic rib and the gluteal folds ${ }^{12)}$ within a day of answering the questionnaire.

The final part of the questionnaire (part 3) focused on psychosocial aspects of work assessed using the Suan Prung stress test, which is widely used for stress measurement in Thailand $^{18,19)}$. There are 20 items in this test that are scored on a 5-point Likert scale with item responses ranging from "0" (no stress) to "5" (extremely high stress). Total scores are categorized into four levels: low stress, medium stress, high stress, and extremely high stress ${ }^{20}$.

Statistical analyses were performed using the Stata program (version 11). Data are presented as means and standard deviations for continuous variables. Frequencies and percentages were examined for category variables. The $\chi^{2}$ test was conducted to test the significance of association among factors and LBP variables, and simple logistic regression was used to explore the association between each candidate and LBP. The variables with a p-value less than 0.25 were included in the initial model of logistic regression ${ }^{16}$. The backward stepwise elimination procedure was used for data analysis. For the final model of logistic regression, the variables with a p-value less than 0.05 were considered to be statistically significant. The odds ratio (OR) showed the magnitude of effect.

\section{RESULTS}

Most subjects in the study were female $(56.10 \%)$. The mean age of all subjects was $44.40 \pm 9.42$ years. The age ranges were divided into 2 groups for the multiple logistic regression model based on functional alteration for LBP of participants that were $\leq 45$ years old and $>45$ years old ${ }^{21)}$. The mean BMI was $23.25 \pm 3.48$. BMI was divided into 4 groups based on the cutoff points for BMI in the Asian population as categorized by the $\mathrm{WHO}^{22}$. More than half of all participants had an abnormal BMI, including obesity (BMI $\geq 25 ; 27.62 \%$ ), overweight (BMI 23-24.9; 21.22\%), and underweight (BMI $<18.5 ; 7.76 \%$ ), respectively. An examination of health behaviors showed that $18.60 \%$ were current smokers, whereas about $13.37 \%$ of all participants were former smokers. About half of the participants reported they never exercised $(50.87 \%)$. Most of the participants $(86.92 \%)$ derived additional income from activities other than rice farming. 
Table 1. Demographic information of rice farmers $(n=344)$

\begin{tabular}{|c|c|c|c|c|}
\hline Demographic characteristic & Number & Percent & Mean & SD \\
\hline \multicolumn{5}{|l|}{ Gender } \\
\hline Male & 151 & 43.9 & & \\
\hline Female & 193 & 56.1 & & \\
\hline Age & & & 44.4 & 9.4 \\
\hline BMI & & & 23.2 & 3.5 \\
\hline \multicolumn{5}{|l|}{ Smoking status } \\
\hline Yes & 64 & 18.6 & & \\
\hline Former & 46 & 13.4 & & \\
\hline No & 234 & 68.0 & & \\
\hline \multicolumn{5}{|l|}{ Additional income } \\
\hline Yes & 299 & 86.9 & & \\
\hline No & 45 & 13.1 & & \\
\hline \multicolumn{5}{|l|}{ Exercise } \\
\hline Never & 175 & 50.9 & & \\
\hline Once a week & 73 & 21.2 & & \\
\hline 2-3 times/week & 69 & 20.1 & & \\
\hline$>3$ times/week & 27 & 7.8 & & \\
\hline Farming experience & & & 24.5 & 12.1 \\
\hline Number of working days & & & 7.2 & 5.7 \\
\hline Number of bundles & & & 44.3 & 19.1 \\
\hline Weight of a bundle & & & 1.9 & 0.5 \\
\hline \multicolumn{5}{|l|}{ Hours transplanting per day } \\
\hline$<7 \mathrm{hr} /$ day & 167 & 48.5 & & \\
\hline$\geq 7 \mathrm{hr} /$ day & 177 & 51.4 & & \\
\hline \multicolumn{5}{|l|}{ Level of stress } \\
\hline Mild & 25 & 7.3 & & \\
\hline Moderate & 166 & 48.3 & & \\
\hline High & 137 & 39.8 & & \\
\hline Extremely high & 16 & 4.6 & & \\
\hline
\end{tabular}

For the farming characteristics, farming experience ranged from 1 to 49 years, with the average being 24.54 years $(\mathrm{SD}=12.07)$. The duration that farmers worked in the field undertaking the rice transplanting process ranged from 1 to 30 days; the mean duration was 7.24 days $(\mathrm{SD}=5.66)$. More than half the farmers $(51.45 \%)$ worked in the field 7 hours or more per day. The number of bundles of seedlings (immature rice plants) used in the process ranged from 6 to 150 bundles, and the mean was 44.31 bundles $(\mathrm{SD}=19.06)$. Most of the farmers used bundles weighing two or less kilograms, with the lightest reported bundle weight being 0.5 kilograms and the heaviest being four kilograms.

The psychosocial factors were measured using the Suan Prung stress test to score stress levels. Most of the farmers in the study had moderate $(48.26 \%)$ and high levels of stress $(39.83 \%)$. Some farmers had severe stress (4.6\%). The demographic data, farming characteristics, and psychosocial factors of the participants are reported in Table 1.

Two hundred and eighty-six participants $(83.14 \%$; $95 \%$ CI 79.16-87.11) experienced LBP during the rice transplanting process. The prevalences of LBP and 95\% CIs in farmers during the rice transplanting process as stratified by age, gender, farming characteristics, and stress level are shown
Table 2. Point prevalence of LBP as stratified by personal factors, farming characteristics, and stress level $(n=344)$

\begin{tabular}{|c|c|c|c|}
\hline Demographic characteristic & Total & $\begin{array}{l}\text { Prevalence } \\
(\%) \text { of LBP }\end{array}$ & $95 \% \mathrm{CI}$ \\
\hline Overall & 344 & 83.1 & $78.8-86.9$ \\
\hline \multicolumn{4}{|l|}{ Gender } \\
\hline Male & 151 & 80.8 & $70.4-84.9$ \\
\hline Female & 193 & 85.0 & $79.1-89.7$ \\
\hline \multicolumn{4}{|l|}{ Age } \\
\hline$\leq 45$ years old & 173 & 86.1 & $80.1-90.9$ \\
\hline$>45$ years old & 171 & 80.1 & $73.3-85.8$ \\
\hline \multicolumn{4}{|l|}{ Farming experience } \\
\hline$<25$ years & 151 & 86.7 & $80.3-91.7$ \\
\hline$\geq 25$ years & 193 & 80.3 & $74.0-85.7$ \\
\hline \multicolumn{4}{|l|}{ Number of working days } \\
\hline$\leq 5$ days & 178 & 86.5 & $80.6-91.2$ \\
\hline$>5$ days & 166 & 79.5 & $72.5-85.4$ \\
\hline \multicolumn{4}{|l|}{ Number of bundles } \\
\hline$<45$ bundles & 197 & 83.8 & $77.9-88.6$ \\
\hline$\geq 45$ bundles & 147 & 82.3 & $75.2-88.1$ \\
\hline \multicolumn{4}{|l|}{ Weight of a bundle } \\
\hline$<2 \mathrm{~kg}$ & 308 & 82.1 & $77.4-86.2$ \\
\hline$\geq 2 \mathrm{~kg}$ & 36 & 91.7 & $77.5-98.2$ \\
\hline \multicolumn{4}{|l|}{ Hours transplanting per day } \\
\hline$<7 \mathrm{hr} /$ day & 167 & 85.0 & $78.7-90.1$ \\
\hline$\geq 7 \mathrm{hr} /$ day & 177 & 81.4 & $74.8-86.8$ \\
\hline \multicolumn{4}{|l|}{ Level of stress* } \\
\hline Mild or moderate & 191 & 78.5 & $72.0-84.1$ \\
\hline High or severe & 153 & 88.9 & $82.8-93.4$ \\
\hline
\end{tabular}

in Table 2. The results revealed that the prevalence of LBP in farmers was only significantly higher according to the level of stress. The prevalence of LBP in farmers with high or severe stress was distinctly higher than in farmers with mild or moderate stress ( 88.89 vs. $78.53 \%$; p value $=0.027$ ) However, farming experience and duration of working in the field slightly trended towards significance $(86.75$ vs. $80.31 \%, \mathrm{p}$ value $=0.069 ; 86.52$ vs. $79.52, \mathrm{p}$ value $=0.057$, respectively).

Table 3 presents the results of the univariate logistic regression analyses for factors with a p-value less than 0.25 and the variables with a $p$-value $>0.25$, including gender, BMI, experience, waist-hip ratio (WHR), smoking status, additional income, exercise, number of bundles, weight of a bundle, and hours per day. The table provides crude ORs to show the association between each factor and LBP, shows the total numbers and percentages of farmers with LBP in each category, and provides $95 \%$ CIs for crudes ORs and $\mathrm{p}$ values. Based on the simple logistic regression analysis, it was found that the level of stress assessed by the Suan Prung test was significantly related to $\mathrm{LBP}\left(\mathrm{OR}_{\text {crude }} 2.2\right.$; $95 \%$ CI 1.2-2.4; $p$ value $=0.012$ ). In addition, other factors that might be associated with LBP in this study ( $p$-value less than 0.25$)$ were age $\left(\mathrm{OR}_{\text {crude }} 0.6 ; 95 \%\right.$ CI $0.4-1.1$; $\mathrm{p}$ value $=$ 
Table 3. OR crude $_{\text {with }} 95 \%$ confidence intervals ( $95 \%$ CIs) of LBP based on simple logistic regression $(n=344)$

\begin{tabular}{lcccc}
\hline $\begin{array}{l}\text { Demographic } \\
\text { characteristic }\end{array}$ & Total & $\begin{array}{l}\text { Prevalence } \\
(\%) \text { of LBP }\end{array}$ & OR $_{\text {crude }}$ & $95 \% \mathrm{CI}$ \\
\hline Age & & & & \\
$\quad \leq 45$ years old & 173 & 86.1 & 1 & \\
$\quad>45$ years old & 171 & 80.1 & 0.6 & $0.4-1.1$ \\
$\quad \begin{array}{l}\text { Experience } \\
\quad<25 \text { years }\end{array}$ & 151 & 86.7 & 1 & \\
$\quad \geq 25$ years & 193 & 80.3 & 1.6 & $0.9-2.9$ \\
$\quad$ Number of days & & & & \\
$\quad \leq 5$ days & 178 & 86.5 & 1 & \\
$\quad>5$ days & 166 & 79.5 & 0.6 & $0.3-1.1$ \\
$\quad$ Weight of a bundle & & & & \\
$\quad<2$ kg & 308 & 82.1 & 1 & \\
$\quad \geq 2$ kg & 36 & 91.7 & 2.4 & $0.7-8.1$ \\
Level of stress* & & & & \\
$\quad \begin{array}{l}\text { Mild or moderate } \\
\text { High or severe }\end{array}$ & 191 & 78.5 & 1 & \\
\hline
\end{tabular}

* Statistically significant ( $\mathrm{p}$-value $<0.05$ )

0.138), farming experience $\left(\mathrm{OR}_{\text {crude }} 1.6 ; 95 \%\right.$ CI $0.9-2.9 ; \mathrm{p}$ value $=0.115)$, duration of working in the field $\left(\mathrm{OR}_{\text {crude }} 0.6\right.$; $95 \%$ CI $0.3-1.1 ; \mathrm{p}$ value $=0.085$ ), and weight of bundles $\left(\mathrm{OR}_{\text {crude }} 2.4 ; 95 \%\right.$ CI $0.7-8.1 ; \mathrm{p}$ value $\left.=0.160\right)$, so these factors were included in the initial model of multiple logistic regression.

Two factors, namely the duration of working in the field and level of stress, were associated with LBP as shown by the adjusted OR and $95 \%$ CI with $\mathrm{p}<0.05$ when controlling the covariate. The magnitude of association with LBP of factors included in the final model is shown by the adjusted OR $\left(\mathrm{OR}_{\mathrm{adj}}\right)$, as reported in Table 4. The duration of working in the rice field was significantly associated with LBP in each age group $(p=0.008)$. The age range significantly influenced the association between the number of days in the field and LBP. The farmers younger than 46 years old who worked in the field $>5$ days were 0.02 times less likely to experience LBP compared with those who worked in the field for $\leq 5$ days $(95 \%$ CI: $0.08-0.61)$. For younger farmers, working in the field $>5$ days was a protective factor for LBP, and the farmers who were $\leq 45$ years old and worked in the field $\leq 5$ days were 5 times more likely to experience LBP than those who worked in the field $>5$ days $\left(\mathrm{OR}_{\text {adj }} 5\right.$; 95\% CI: 1.6-11.12). In contrast, among those $>45$ years old, the corresponding $\mathrm{OR}_{\mathrm{adj}}$ was only 1.2 (95\% CI: 0.57-2.60). Another factor that was strongly associated with LBP was a high or extremely high level of stress as measured by the Suan Prung stress test $\left(\mathrm{OR}_{\mathrm{adj}} 2.2 ; 95 \%\right.$ CI $1.17-4.10 ; \mathrm{p}=$ $0.01)$.

\section{DISCUSSION}

This study demonstrated the point prevalence of LBP and associated factors among Thai farmers during the rice transplanting process. The results of the current study

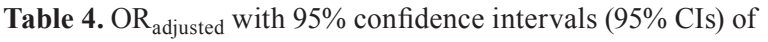
LBP symptoms based on multiple logistic regression (n $=344)$

\begin{tabular}{|c|c|c|c|c|}
\hline $\begin{array}{l}\text { Demographic } \\
\text { characteristic }\end{array}$ & Total & $\begin{array}{l}\text { Prevalence } \\
(\%) \text { of LBP }\end{array}$ & $\mathrm{OR}_{\text {adj }}$ & $95 \% \mathrm{CI}$ \\
\hline \multicolumn{5}{|c|}{ The number of working days in a field for each group of age* } \\
\hline \multicolumn{5}{|l|}{$\leq 45$ years old } \\
\hline$\leq 5$ days & 93 & 93.5 & 1 & \\
\hline$>5$ days & 80 & 77.5 & 0.2 & $0.1-0.6$ \\
\hline \multicolumn{5}{|l|}{$>45$ years old } \\
\hline$\leq 5$ days & 85 & 78.8 & 1 & \\
\hline$>5$ days & 86 & 81.4 & 1.2 & $0.6-2.6$ \\
\hline \multicolumn{5}{|l|}{ Level of stress* } \\
\hline Mild or moderate & 191 & 78.5 & 1 & \\
\hline High or severe & 153 & 88.9 & 2.2 & $1.2-4.1$ \\
\hline
\end{tabular}

${ }^{*}$ Statistically significant ( $\mathrm{p}$-value $<0.05$ )

showed a very high prevalence $(83.14 \%)$ of LBP in all farmers. In previous studies, a higher prevalence of LBP was found in occupations with high excessive loads or poor working postures, such as those experienced by industrial workers $^{12,23)}$, vehicle drivers ${ }^{24)}$, and farmers ${ }^{25)}$, than in other manual workers because of job intensity and poor working postures ${ }^{5)}$. Other studies have shown a high prevalence of LBP among Thai rice farmers, with the prevalence ranging from $50-76 \%{ }^{1,2)}$. The results of the current study confirm results from previous studies and indicate that LBP is a common and concerning health problem for Thai rice farmers. Our study indicated that the prevalence of LBP was slightly higher than those in the two previous studies. The higher prevalence in the current study may be because the data gathering in the current study was undertaken during the rice transplanting period, whereas in the two previous studies, data were collected out of season. However, the prevalence of LBP among rice farmers in India was slightly higher than in the current study (the prevalence of LBP there was reported to be $99 \%)^{26)}$.

The high prevalence of LBP among farmers is most likely the result of injury to the spinal structures, which may arise from working postures and movements of the lower back during the work process. The study from India analyzed farming postures and showed that the farmers were working with forward lumbar bending and twisting and were carrying weights of $10 \mathrm{~kg}$ or less and that these postures seemed to generate their $\mathrm{LBP}^{26)}$. A number of other authors have reported that these working postures are associated with $\mathrm{LBP}^{25}$. The postures in the rice transplanting process are awkward, constrained, asymmetric, repeated, and prolonged. These postures can generate load on the lumbar region, which can overload tissues and exceed their thresholds of tolerable stress, causing injury due to overexertion or imbalance ${ }^{27)}$. For example, the maintenance of static postures for prolonged periods of time compresses the veins and capillaries inside the muscles, causing micro lesions due to the absence of tissue oxygenation and nutrition. Some rice farming tasks cannot be easily separated from the transplanting process. Farmers perform other tasks concurrently in the paddy field 
such as uprooting and carrying bundles of saplings. Farmers work in squat postures and reach with their arms to pull and uproot saplings, an activity that increases the load on their lumbar region. All of these factors can contribute to imbalance, fatigue, discomfort, and pain due to disruption of tissues ${ }^{28)}$.

Regarding the aspects of prevalence stratified by personal characteristics, farming characteristics, and stress levels, the results of the current study showed that the prevalence of LBP was significantly higher in the farmers with high or severe stress levels. This result confirms that farmers with high stress were more likely to have LBP. In the current study, the prevalence of stress among females was slightly higher than in males, but this was not significant. This result is consistent with a previous study that reported that the prevalence of LBP was not differentiated by gender ${ }^{29}$ ). Other variables including work experience and hours worked per day also showed no statistically significant association with LBP in the current study, although previous studies have reported differences ${ }^{29)}$.

LBP disorders may occur due to many factors. Previous studies have reported that the personal characteristics associated with LBP were age, BMI, exercise, alcohol consumption, and smoking ${ }^{7,30)}$. In the present study, only age was related to LBP, which confirms results from some previous studies $^{12,31)}$. The present study found that the number of days in the field and signs and symptoms of stress were related to $\mathrm{LBP}\left(\mathrm{OR}_{\text {adj }} 5,95 \% \mathrm{CI} 1.6-11.12, \mathrm{p}=0.008 ; \mathrm{OR}_{\text {adj }} 2.2,95 \%\right.$ CI $1.21-4.00, \mathrm{p}=0.01$, respectively) but that the odds ratio was dependent on the age of each group. In this study, the interaction between the number of days in the field and LBP was significant in different age groups. The farmers who were 45 years of age or younger and worked in the field five days or less were 5 times more likely to experience LBP than those who worked in the field more than five days. This finding in the current study, that is, that number of working days in the field is associated with LBP, has not been reported in previous studies. This finding may be due to the process of delayed onset muscle soreness (DOMS) and adaptation. As already mentioned, working in the rice transplanting process involves work postures and activities of repetitive stooping and twisting that activate the back muscles to act in an eccentric contraction (lengthening under load). The literature reviewed supports the concept that when muscles act in repeated eccentric contraction, damage can occur. DOMS begins within 12 hours after unaccustomed activity, persists for $2-5$ days, and then decreases due to adaptation ${ }^{32}$. Hodge stated that pain or injury can be decreased by redistribution of activity between muscles ${ }^{33)}$. This may be the reason for our finding that the prevalence of LBP was higher in the farmers who worked for 5 days or less compared with the farmers who worked more than 5 days.

Additionally, this finding suggests that age modified the association of number of days working in a field with LBP. The results demonstrated that the adjusted OR value for farmers in the group aged 45 years or less was 0.2 , indicating that age is a protective factor. Our results show that the farmers aged 45 year or less were 5 times more likely to experience LBP than those who worked in the field more than five days per week. The younger age group may have additional job requirements such as uprooting, plowing, or harrowing the field before transplanting and carrying saplings. Furthermore, the age range of the younger group was wider than the older group, which could include more farmers with LBP than the other group. Nevertheless, this finding seems to contrast with a previous study reporting that LBP increased with increasing age ${ }^{34)}$ which was attributed to degenerative effects.

For farming characteristics, analysis of the crude ORs indicated no significant association between LBP and years of farming experience, hours of working per day, or weight of bundles. Workers who worked for a few years had a greater incidence for LBP. Our results showed a trend towards significance of work experience that aligns with the existing literature, which shows that the farmers with less than a year of experience in farming tend to experience $\mathrm{LBP}^{35}$. A possible reason for is that more experienced workers adapt their manner of work to appropriately perform their jobs and develop motor control to reduce spinal loading during task performance ${ }^{36)}$. However, this should be investigated further because recent studies have reported that years of farming experience (at least 30 years farming experience) was associated with a high risk of clinical lumbar instability ${ }^{37)}$. For other farming characteristics, there are research findings from other studies ${ }^{38,39)}$ concerning hours of work per day and work while carrying a load, which were not significant in the current study. In previous studies, investigators also reported that LBP was related to long working hours and working while carrying a load ${ }^{38,40)}$.

The Suan Prung stress test was used to evaluate psychosocial factors in the current study. The results showed that the farmers with high or extremely high stress levels were twice as likely to experience LBP than the group with mild or moderate stress levels. This finding confirms results from previous studies indicating that stress is related to $\mathrm{LBP}^{8)}$. The findings from previous studies reveal that the psychosocial factors related to LBP are anxiety, depression, somatization of symptoms, stress, job dissatisfaction, negative body image, and low self-efficacy ${ }^{8,10}$. Psychosocial factors were associated with LBP through a mechanism that generated trunk muscle co-activation and influenced spinal loading ${ }^{15}$.

The results demonstrated that almost all Thai farmers who participated in the current study experienced LBP. Moreover, the number of working days in the field in the younger age group and stress levels were associated with LBP during rice transplanting. LBP is a serious occupational issue for Thai rice farmers. The point time prevalence in this study indicated that symptoms may reflect acute LBP experienced by farmers during the rice transplanting process from which they can recover rapidly. Furthermore, after the transplanting process, the work the farmer will undertake is "lighter" than in the transplanting process. Thus, LBP could be reduced with good pain management. The large sample size in this study was sufficient to find a high prevalence of LBP during the rice transplanting process. Further, the high prevalence found in the transplanting process in the current study could be due to pain continuing from farming processes immediately prior to rice transplanting. In the current study the authors did not investigate working postures because most farmers work in similar postures during the 
transplanting process. Thus, the current study emphasizes farmer characteristics that comprise external load factors.

In this study, the investigators did not differentiate current symptoms during the transplanting process from symptoms arising from work before the transplanting process, meaning that existing symptoms from the previous process may not have abated by the time the farmers started on the rice transplanting process. The study was conducted in only one province, which limits generalizations associated with the findings. The larger sample size in this study was sufficient to find a high prevalence of LBP during the rice transplanting process. Further study should be conducted to try to determine the time at which pain originated and to investigate a larger geographical area to determine if the problems found in this study might apply to farmers throughout the country.

The findings of the current study suggest that LBP is a serious problem for rice farmers during the rice transplanting process. Farmers are required to work in postures with high risk factors for LBP, causing soft tissue injuries around their spinal structures. The tissues most particularly linked to LBP in this study arose from muscles and joints. LBP was associated not only with working postures but also with age, number of days in the field, and stress. LBP was mostly reported by younger farmers with less experience of working in the field. These results indicate the need to help prevent and manage LBP experienced by rice farmers during the rice transplanting process. As practical suggestions, exercise, massage therapy, and lumbar supports are effective treatments and tools to release muscle stiffness, decrease pain, and improve physical functions ${ }^{41-44}$ ). These combinations of physical therapy can provide beneficial effects on muscle relaxation and spinal alignment for LBP in rice farmers.

\section{ACKNOWLEDGEMENT}

This study was supported by grants from the Research Center in Back, Neck, Other Joint Pain and Human Performance (BNOJPH) and Khon Kaen University. In addition, this study was primary supported by grants from the Coordinating Center for Thai Government Science and Technology Scholarship Students (CSTS) and National Science and Technology Development Agency (NSTDA) (No. SCH-NR2012-124). The opinions expressed in this paper are those of the authors and do not necessarily reflect the views of the CSTS or NSTDA.

\section{REFERENCES}

1) Puntumetakul R, Siritaratiwat W, Boonprakob Y, et al.: Prevalence of musculoskeletal disorders in farmers: case study in Sila, Muang Khon Kaen, Khon Kaen province. J Med Technol Phys Ther, 2011, 23: 297-303.

2) Taechasubamorn P, Nopkesorn T, Pannarunothai S: Prevalence of low back pain among rice farmers in a rural community in Thailand. J Med Assoc Thai, 2011, 94: 616-621. [Medline]

3) Chung SH, Her JG, Ko T, et al.: Work-related musculoskeletal disorders among Korean physical therapists. J Phys Ther Sci, 2013, 25: 55-59. [CrossRef]

4) Rosecrance J, Rodgers G, Merlino L: Low back pain and musculoskeletal symptoms among Kansas farmers. Am J Ind Med, 2006, 49: 547-556. [Medline] [CrossRef]

5) Walker-Bone K, Palmer KT: Musculoskeletal disorders in farmers and farm workers. Occup Med (Lond), 2002, 52: 441-450. [Medline] [Cross-
Ref]

6) Taspinar F, Taspinar B, Cavlak U, et al.: Determining the pain-affecting factors of university students with nonspecific low back pain. J Phys Ther Sci, 2013, 25: 1561-1564. [Medline] [CrossRef]

7) Govindu NK, Babski-Reeves K: Effects of personal, psychosocial and occupational factors on low back pain severity in workers. Int J Ind Ergon, 2014, 44: 335-341. [CrossRef]

8) Pincus T, Burton AK, Vogel S, et al.: A systematic review of psychological factors as predictors of chronicity/disability in prospective cohorts of low back pain. Spine, 2002, 27: E109-E120. [Medline] [CrossRef]

9) Heneweer H, Staes F, Aufdemkampe G, et al.: Physical activity and low back pain: a systematic review of recent literature. Eur Spine J, 2011, 20: 826-845. [Medline] [CrossRef]

10) Kai S: Consideration of low back pain in health and welfare workers. J Phys Ther Sci, 2001, 13: 149-152. [CrossRef]

11) Frymoyer JW, Pope MH, Costanza MC, et al.: Epidemiologic studies of low-back pain. Spine, 1980, 5: 419-423. [Medline] [CrossRef]

12) Keawduangdee P, Puntumetakul R, Chatchawan U, et al.: Prevalence and associated risk factors of low-back pain in textile fishing net manufacturing. Hum Factors Ergon Manuf Serv Ind, 2012, 22: 562-570. [CrossRef]

13) Murtezani A, Hundozi H, Orovcanec N, et al.: Low back pain predict sickness absence among power plant workers. Indian J Occup Environ Med, 2010, 14: 49-53. [Medline] [CrossRef]

14) Radwin RG, Marras WS, Lavender SA: Biomechanical aspects of work-related musculoskeletal disorders. Theor Issues Ergon Sci, 2001, 2: 153-217. [CrossRef]

15) Marras WS: Occupational low back disorder causation and control. Ergonomics, 2000, 43: 880-902. [Medline] [CrossRef]

16) Hsieh FY, Bloch DA, Larsen MD: A simple method of sample size calculation for linear and logistic regression. Stat Med, 1998, 17: 1623-1634. [Medline] [CrossRef]

17) Kuorinka I, Jonsson B, Kilbom A, et al.: Standardised Nordic questionnaires for the analysis of musculoskeletal symptoms. Appl Ergon, 1987, 18: 233-237. [Medline] [CrossRef]

18) Chumthi LO: Effect of foot reflexology on stress reduction among adolescent. R Thai Airf Med Gaz, 2012, 57: 24-35.

19) Janwantanakul P, Pensri P, Moolkay P, et al.: Development of a risk score for low back pain in office workers - a cross-sectional study. BMC Musculoskelet Disord, 2011, 12: 23. [Medline] [CrossRef]

20) Mahatnirunkul S, Poompaisarnchai W, Tapanya P: The construction of Suan Prung Stress Test for Thai population. Bull Suan Prung, 1997, 13: $1-20$.

21) Manchikanti L, Singh V, Datta S, et al. American Society of Interventional Pain Physicians: Comprehensive review of epidemiology, scope, and impact of spinal pain. Pain Physician, 2009, 12: E35-E70. [Medline]

22) Kantachuvessiri A: Obesity in Thailand. J Med Assoc Thai, 2005, 88: 554-562. [Medline]

23) Yildirim Y, Gunay S, Karadibak D: Identifying factors associated with low back pain among employees working at a package producing industry. J Back Musculoskeletal Rehabil, 2014, 27: 25-32. [Medline]

24) Bovenzi M, Rui F, Negro C, et al.: An epidemiological study of low back pain in professional drivers. J Sound Vibrat, 2006, 298: 514-539. [CrossRef]

25) Khan AA, Uddin MM, Chowdhury AH, et al.: Association of low back pain with common risk factors: a community based study. Indian J Med Res, 2014, 25: 50-55.

26) Das B, Gangopadhyay S: An ergonomics evaluation of posture related discomfort and occupational health problems among rice farmers. Occup Ergon. 2011, 10: 25-38.

27) Kumar S: Theories of musculoskeletal injury causation. Ergonomics, 2001, 44: 17-47. [Medline] [CrossRef]

28) Kumar S: A conceptual model of overexertion [correction of oxerexertion], safety, and risk of injury in occupational settings. Hum Factors, 1994, 36: 197-209. [Medline]

29) Osborne A, Finnegan G, Blake C, et al.: An evaluation of low back pain among farmers in Ireland. Occup Med (Lond), 2013, 63: 53-59. [Medline] [CrossRef]

30) Ferguson SA, Marras WS: A literature review of low back disorder surveillance measures and risk factors. Clin Biomech (Bristol, Avon), 1997, 12: 211-226. [Medline] [CrossRef]

31) Campo MA, Weiser S, Koenig KL: Job strain in physical therapists. Phys Ther, 2009, 89: 946-956. [Medline] [CrossRef]

32) Nelson N: Delayed onset muscle soreness: is massage effective? J Bodyw Mov Ther, 2013, 17: 475-482. [Medline] [CrossRef]

33) Hodges PW: Pain and motor control: from the laboratory to rehabilitation. J Electromyogr Kinesiol, 2011, 21: 220-228. [Medline] [CrossRef] 
34) Driscoll T, Jacklyn G, Orchard J, et al.: The global burden of occupationally related low back pain: estimates from the Global Burden of Disease 2010 study. Ann Rheum Dis, 2014, 73: 975-981. [Medline] [CrossRef]

35) Sprince N, Park H, Zwerling C, et al.: Risk factors for low back injury among farmers in Iowa: a case-control study nested in the agricultura health study. J Occup Environ Hyg, 2007, 4: 10-16. [Medline] [CrossRef]

36) Bigos SJ, Spengler DM, Martin NA, et al.: Back injuries in industry: a retrospective study. III. Employee-related factors. Spine, 1986, 11: 252-256. [Medline] [CrossRef]

37) Puntumetakul R, Yodchaisarn W, Emasithi A, et al.: Prevalence and individual risk factors associated with clinical lumbar instability in rice farmers with low back pain. Patient Prefer Adherence, 2015, 9: 1-7. [Medline]

38) Osborne A, Blake C, McNamara J, et al.: Musculoskeletal disorders among Irish farmers. Occup Med (Lond), 2010, 60: 598-603. [Medline] [CrossRef]

39) Fethke NB, Merlino LA, Gerr F, et al.: Musculoskeletal pain among midwest farmers and associations with agricultural activities. Am J Ind Med, 2015, 58: 319-330. [Medline] [CrossRef]

40) Naidoo S, Kromhout H, London L, et al.: Musculoskeletal pain in women working in small-scale agriculture in South Africa. Am J Ind Med, 2009, 52: 202-209. [Medline] [CrossRef]

41) Areeudomwong P, Puntumetakul R, Jirarattanaphochai K, et al.: Core stabilization exercise improves pain intensity, functional disability and trunk muscle activity of patients with clinical lumbar instability: a pilot randomized controlled study. J Phys Ther Sci, 2012, 24: 1007-1012. [CrossRef]

42) Hongsuwan C, Eungpinichpong W, Chatchawan U, et al.: Effects of Thai massage on physical fitness in soccer players. J Phys Ther Sci, 2015, 27: 505-508. [Medline] [CrossRef]

43) Peungsuwan P, Sermcheep P, Harnmontree P, et al.: The effectiveness of Thai exercise with traditional massage on the pain, walking ability and QOL of older people with knee osteoarthritis: a randomized controlled trial in the community. J Phys Ther Sci, 2014, 26: 139-144. [Medline] [CrossRef]

44) Prommanon B, Puntumetakul R, Peungsuwan P, et al.: Effectiveness of back care pillow as an adjuvant physical therapy in chronic non-specific low back pain treatment: a randomized controlled trial. J Phys Ther Sci, (In press). 